\title{
Drying Mechanism of Unutilized Cedar Logs as a Source of Heating Fuel
}

\author{
V. H. Hoang, S. Nagasaki, Y. Kawabata, T. Wajima, and H. Nakagome
}

\begin{abstract}
In Japan, small, forested areas are often destroyed because neglect due to a slump in wood prices and a shortage of labor. Promotion of forest maintenance along with the use of unused woody biomass is desired. In this study, the drying mechanism of Cedar (Cryptomeria japonica) logs destined to be used as heating was examined. The experimental results show that cedar samples reached the fiber saturation point after 4-5 months of drying on site. The water in the wood moved to the cut ends and evaporated because of the high pressure differences on the surfaces of the cut ends. The water content in the center of the logs was higher than that at the cut ends because closed pits in the vessel structures prevented the passage of water.
\end{abstract}

Index Terms - Unused woody biomass, cedar log, drying, heat utilization.

\section{INTRODUCTION}

Increased $\mathrm{CO}_{2}$ in the atmosphere caused by the excessive use of fossil fuels has damaged the natural environment and made global warming a worldwide issue. To overcome this problem, $\mathrm{CO}_{2}$ emissions need to be reduced by promoting the introduction of renewable energy sources.

With regard to woody biomass resources, little of Japan's abundant forest resources are used because of the decline of the domestic forestry industry, which resulted from an influx of cheap, foreign wood materials. Untended, unlogged forests have been linked to an increasing number of landslides, which have become a serious problem for rural areas.

One of the most effective ways to solve all these problems is to use woody biomass as a carbon-neutral energy resource [1]. Biomass can be used for heat and power generation. In the conversion of woody biomass to energy, the woody biomass can be burned directly, pyrolyzed, or gasified to produce flammable gas, which can be used for energy or converted into liquid fuel [2]-[5]. With regard to the use of woody biomass in rural areas, we proposed directly burning the woody biomass as fuel for heaters because the preparation of logs for fuel is a shorter process in comparison with other biomass fuels, such as pellets or chips.

The method of drying the wood is an important step in the development of energy generation. Woody biomass needs to be dried before energy conversion, as green woody biomass normally has a moisture content of 50-60\%. Most of the water contained in the biomass must be removed to increase the

Manuscript received September 5, 2014; revised November 7, 2014. This work was supported by the Forestry Agency (Programs to promote the model area that utilizes woody biomass energy).

Hoang Van Hieu is with the Department of Urban Environment Systems, Graduate School of Engineering, Chiba University, Japan (e-mail: hoanghieu@chiba-u.jp). conversion efficiency and to reduce emissions. The target moisture content after drying varies from 2 to $20 \%$, depending on the conversion technologies used [6].

Biomass with lower moisture content could minimize or eliminate other combustion control problems caused by fluctuations in fuel moisture. Nonetheless, drying is an energy-intensive process and can easily account for up to $15 \%$ of industrial energy use [7]. Consequently, in many industrial drying processes, a large fraction of the energy is wasted [8]. Therefore, energy management is an essential part of any drying process, and energy conservation can significantly lower the overall operating costs [9].

Drying is the process by which water is removed from materials, which involves simultaneous heat and mass transfer. Useful drying models are those that can capture the physical variables of the drying process. They should also be accurate, simple, and robust, as well as requiring only a short computational time favorable for rapid decision-making in industry. It is recognized that drying is an energy-intensive process, as heat is needed to evaporate water [10]. Therefore, a natural drying process, sun drying, is better than forced-drying methods in terms of energy savings for the energy systems of rural areas.

In this study, the drying mechanism of Japanese cedar (Cryptomeria japonica) logs to be used as heating fuel was examined.

\section{MAteriaLS AND MethodS}

\section{A. Samples}

The cedar logs used in this study were collected from a forested area in Sanmu, Chiba prefecture, Japan. Green cedar was logged, and immediately used as samples in the drying test.

We prepared two types of log samples by logging cedar to lengths of $4 \mathrm{~m}(4-\mathrm{m} \log )$ and $0.5 \mathrm{~m}(0.5-\mathrm{m} \operatorname{logs})$, (Fig. 1 (a), (b)). The single 4-m log was $0.2 \mathrm{~m}$ in diameter, with a weight of $124 \mathrm{~kg}$, and the eight $0.5-\mathrm{m} \operatorname{logs}$ were $0.14 \mathrm{~m}$ in diameter, with a weight of $6 \mathrm{~kg}$. The $0.5-\mathrm{m} \operatorname{logs}$ were stacked as shown in Fig. 1 (b). The site of the drying experiment was an area on the campus of Chiba University that was paved with concrete, which had good ventilation and plenty of sunlight (see Fig. 2).
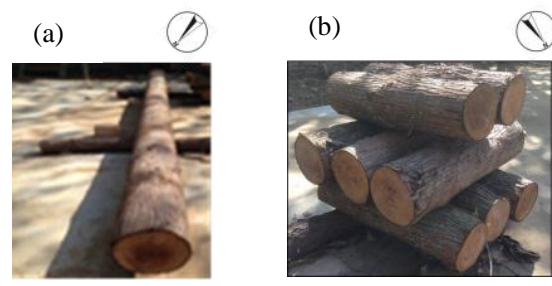

Fig. 1. Samples for the drying experiment. (a) 4-m log, (b) $0.5-\mathrm{m} \log$. 


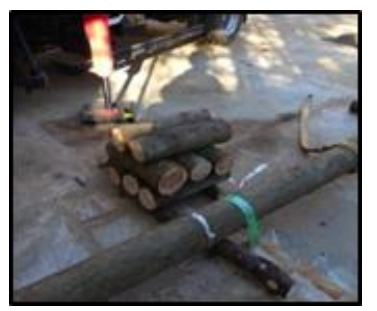

Fig. 2. Study site (university campus).

(a)

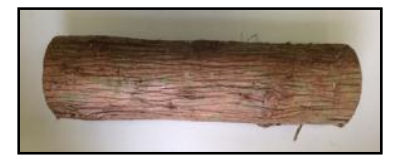

(c)
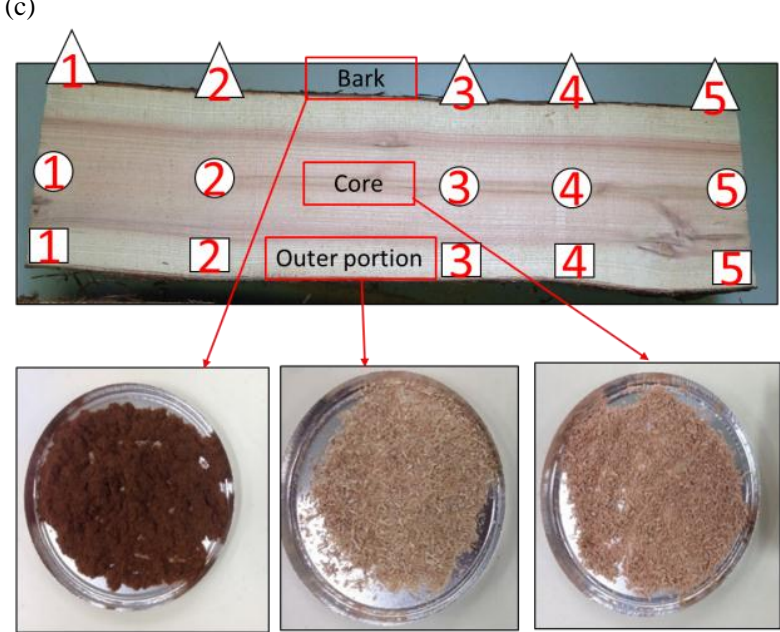

Fig. 3. Samples for water content measurements.

(a)Sample log, (b) Sheared log, (c) Sampling points for moisture measurement.

\section{B. Specific Gravity}

The specific gravity of the log samples was measured to monitor the drying process. The initial specific gravity of the 4-m log was $1.05 \mathrm{~g} / \mathrm{cm}^{3}$, and the average initial specific gravity of the $0.5-\mathrm{m} \operatorname{logs}$ was $0.99 \mathrm{~g} / \mathrm{cm}^{3}$.

Drying rates were estimated from the changes in specific gravity using first order (equation (1)) and second order (equation (2)) reaction formulae.

$$
\begin{aligned}
& v=-\frac{d W}{d t}=k_{1} W \\
& v=-\frac{d W}{d t}=k_{2} W^{2}
\end{aligned}
$$

These equations were transformed into equations ( 3 ) and (4), respectively.

$$
\begin{gathered}
\ln \frac{W}{W_{0}}=-k_{1} t \\
\frac{1}{W}-\frac{1}{W_{0}}=k_{2} t
\end{gathered}
$$

$v:$ Rate of decrease of specific gravity $\left[\mathrm{g} /\left(\mathrm{cm}^{3}\right.\right.$.day $\left.)\right]$

$$
W: \text { Measured specific gravity } \quad\left[\mathrm{g} / \mathrm{cm}^{3}\right]
$$$$
W_{0}: \text { Initial specific gravity } \quad\left[\mathrm{g} / \mathrm{cm}^{3}\right]
$$

$k_{1}$ : Constant of the first order reaction $\left[\mathrm{day}^{-1}\right]$ $k_{2}$ : Constant of the second order reaction $\left[\mathrm{cm}^{3} /(\mathrm{g}\right.$.day) $]$

\section{Water Content Measurement}

The water distribution in the $0.5-\mathrm{m} \log$ (Fig. 3 (a)) was measured before and after the experiment (green log and dried $\log$, respectively) to characterize the drying process. The log was cut in half in a radial direction (Fig. 3 (b)). After dividing half the log into three parts (bark, outer portion and core), the water content was measured at five locations in the horizontal direction, for a total of 15 measured locations. We ground each part into powder with a power grinder, and then measured the water content of the samples using a moisture meter (Sartorius MA35 Moisture Analyzer) (Fig. 3 (c)).

\section{RESUlTS AND DisCUSSION}

\section{A. Effect of Log Length on Drying}

Fig. 4 shows the change in the specific gravity of the two types of logs, and Table I shows the parameters for changes in the specific gravity calculated using the first and second order reaction models. The regression coefficients $\left(R^{2}\right)$ for the first and second order models were almost the same, which means that the drying reaction can be represented by 1-2 order reactions. The decreasing rate constants of the specific gravity of the $0.5-\mathrm{m} \operatorname{logs}$ were 1.6-1.9 times higher than that of the 4-m log, indicating that short logs dry more rapidly than long logs.

According to Fig. 4, the specific gravity of the two samples was reduced to $0.6 \mathrm{~g} / \mathrm{cm}^{3}$ after 180 days. In wood, water is mainly present as free and bound water. Free water is easily evaporated from wood during drying, and all free water is removed during the dry process, after which only bound water remains. This point is known as the fiber saturation point (FSP). The water content of the FSP for cedar is about $30 \%$ $\left(0.6 \mathrm{~g} / \mathrm{cm}^{3}\right.$ specific gravity) [11]. It is considered that the cedar samples used in this study reached the FSP after 4-5 months of drying on the campus site.

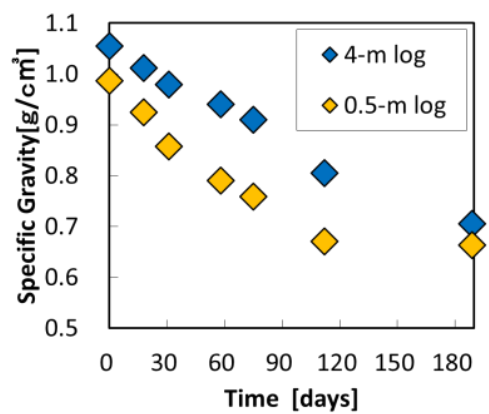

\begin{tabular}{|c|c|c|c|c|}
\hline \multirow[b]{2}{*}{ Sample } & \multicolumn{2}{|c|}{ First Order Reaction } & \multicolumn{2}{|c|}{ Second Order Reaction } \\
\hline & $\mathrm{k}_{1} \times 10^{-3} \quad\left[\mathrm{day}^{-1}\right]$ & $R^{2}$ & $\mathrm{k}_{2} \times 10^{-3}\left[\mathrm{~cm}^{3} /(\mathrm{g}\right.$. day $\left.)\right]$ & $R^{2}$ \\
\hline 4-m log & 2.2 & 0.976 & 2.4 & 0.961 \\
\hline $0.5-\mathrm{m} \log$ & 3.6 & 0.987 & 4.6 & 0.995 \\
\hline
\end{tabular}

Fig. 4. Changes in the specific gravity of dried logs as a function of drying time.

TABLE I: PARAMETERS OF FIRST AND SECOND ORDER REACTIONS FOR LOG DRYING 


\section{B. Water Content}

(a)

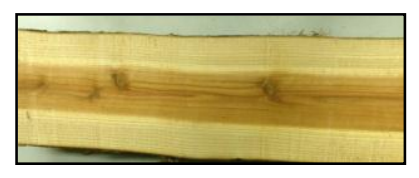

(c)

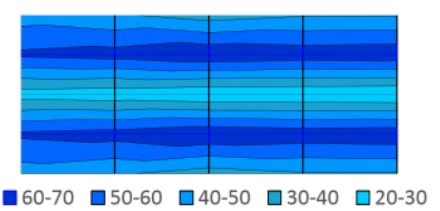

(b)

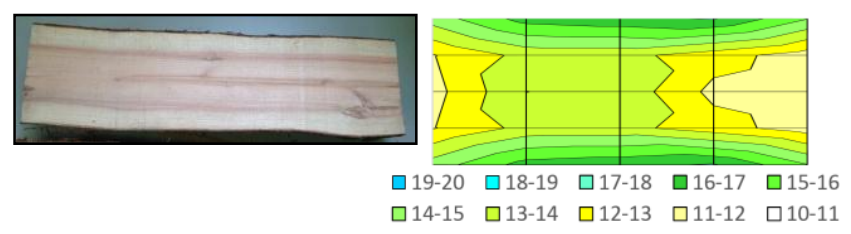

Fig. 5. Moisture distribution in green and dried logs.

(a) Green log, (b) Dried log, (c) Moisture distribution of a green log, (d) Moisture distribution of a dried log.

Fig. 5 shows the moisture distribution of green (Fig. 5 (a), (c)) and dried logs (Fig. 5 (b), (d)). For the green log (Fig. 5 (a)), the horizontal water distributions in the bark, outer portion, and core were almost constant, and the water contents of the bark, outer portion, and core were 40, 65, and 25\%, respectively (Fig. 5 (c)). According to a report by the Forest Products Research Institute in December 2012, the water contents of the core and outer portion of cedar are $35 \%$ and $61 \%$, respectively [12], which is in good agreement with our experimental results.

The outer parts of cedar, which are formed from cells responsible for water transport and nutrient accumulation, have physiological activities, while the core of cedar, which is formed from dead cells, has no physiological activity [13]. Therefore, the outer parts of cedar have higher water contents than the core, and we can conclude that the drying process is greatly affected by the water content of the outer part of the $\log$.

With regard to the horizontal water distributions in the bark, outer part, and core, the water contents of each part of the dried logs (Fig. 5 (b)) were higher at the center of the log (Fig. 5 (d)). In addition, with regard to the vertical water distribution in the logs, the water content of the bark on the dried $\log$ was $14-17 \%$, which was higher than those of the other parts of the log and lower than those of the green log. The core and outer part of the log had water contents of $11-13 \%$ and $12-14 \%$, respectively, which were lower than those in the green log.

The bark is divided into the inner and outer bark. The inner bark is formed from cells that are responsible for nutrient accumulation, while the outer bark is structured to prevent the passage of the water, and it is responsible for protecting the cells of the inner bark. Thus, the reduction in the water content of the bark was caused by the drying of the inner bark, as the water in the wood cannot pass through the outer bark, and, therefore, it cannot be transferred to, or evaporate from, the cut ends.

The water contents of the core and outer part of the dried $\log$ were about $12 \%$, considerably lower than those of the green $\log$, while the cut ends of the logs had the lowest water contents. It is likely that water in the wood moves to the cut

ends and evaporates because of the high pressure differences on the surfaces of the cut ends.

(a) Inside

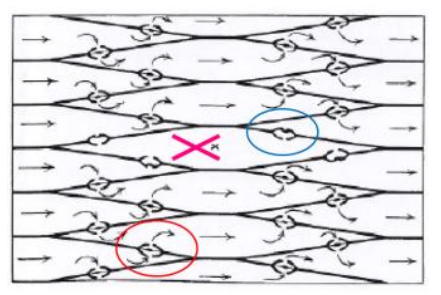

Cut end

Tangential Direction

Fiber Direction

(b)

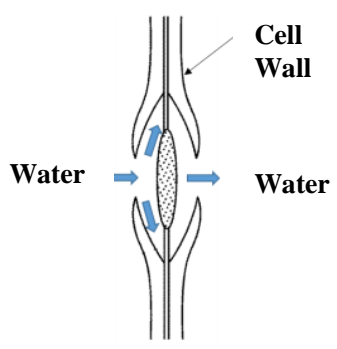

(c)

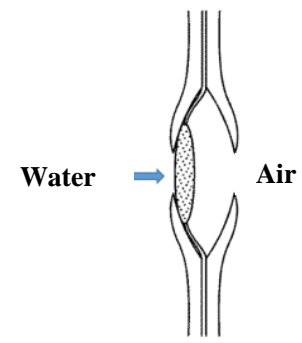

Fig. 6. Scheme of drying of a cedar log.

(a) Schematic diagram of the cross section of a conifer tree,(b) Normal pit, (c) Blocked pit .

Fig. 6 shows the schematic for the drying mechanism for cedar logs. In the case of cedar (a coniferous tree), the water conductivity of the vessels occurs through ray tissue in the direction of the fiber, and it is difficult for water to move in the radial direction (Fig. 6 (a)) [14]. Thus, water starts to evaporate from the surface of the cut ends, and water molecules in the wood move through the cell walls to the cut ends because of the difference in water contents. In wood, water passes through the pits in the cell walls (Fig. 6 (b)), and the pits block the water movement when one side of the cell wall lacks water (Fig. 6 (c)). It has been noted that the core of the log has no physiological activity, and free water is absorbed in the cavities of vessels. Because of the movement of free water, the blocking of pits also occurs. For these reasons, the water content in the center of the fiber is higher than those of the cut ends because the passage of the remaining water is blocked by closed pits.

\section{REFERENCES}

[1] T. Kimura, T. Sugiyama, M. Yamada, and S. Tongu, "Promotion of the "Wood biomass local recycling system business model project," in Proc. Grand Renewable Energy 2014 International Conf. and Exhibition, P-Bm-2-11, Tokyo, Japan, 2014.

[2] S. Pang and J. Li, "Biomass integrated gasification combined cycle system for New Zealand: An overview and perspective," New Zealand Journal of Forestry, vol. 51, pp. 7-12, 2006.

[3] V. C. Highman and M. van der Burgt, Gasification, Elsevier, Amsterdam, 2003.

[4] A. V. Bridgwater and G. Grassi, Biomass Pyrolysis Liquids: Upgrading and Utilisation, Elsevier Applied Science, New York, 1991.

[5] P. T. Lu, "Wood pyrolysis for liquid fuel," B.E. Report, Department of Chemical and Process Engineering, University of Canterbury, NewZealand, 2006.

[6] Q. Xu and S. Pang. (October 2008). Mathematical modeling of rotary drying of woody biomass. Drying Technology: An International Journal. [Online]. 26. pp. 1340-1350. Available: http://www.tandfonline.com/loi/ldrt20

[7] K. J. Chua, A. S. Mujumdar, M. N. A. Hawlader, S. K. Chou, and J. C. Ho, "Batch drying of banana pieces - Effect of stepwise change in drying air temperature on drying kinetics and product color," Food Res. Int., vol. 34, pp. 721-731, 2001. 
[8] H. Ogura, T. Yamamoto, Y. Otsubo, H. Ishida, H. Kage, and A. S. Mujumdar, "A control strategy for chemical heat pump dryer," Dry, Technology, vol. 23, pp. 1189-1203, 2005.

[9] J. C. Ho, S. K. Chou, A. S. Mujumdar, M. N. A. Hawlader, and K. J. Chua, "An optimization framework for drying of heat sensitive products," Appl. Therm. Eng., vol. 21, pp. 1779-1798, 2001.

[10] A. Putranto, Z. Xiao, X. D. Chen, and P. Webley, "Intermittent drying of mango tissues: implementation of the reaction engineering approach," Ind. Eng. Chem. Res., vol. 50, pp. 1089-1098, 2011.

[11] S. Terazawa, Mokuzaikansou No Subete, $1^{\text {st }}$ Series, Kaiseisha, pp. 145-147, 1994.

[12] T. Yamazaki. (December 2012). Mokuzai to Mizu no Kankei. Forest Products Research Institute. [Online]. Available: http:/l http://www.fpri.hro.or.jp/dayori/dayori2012.htm
[13] K. Kawase, "Shimpan Rinsangaku Gairon," Hokkaido University Tosho Kankoukai, 1982.

[14] T. Takahashi, Mokuzai Kagaku Kouza 3 Butsuri, Kaiseisha, 1992.

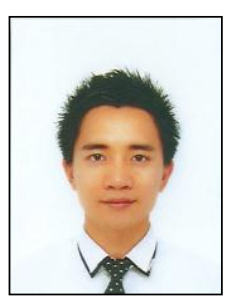

Hoang Van Hieu is from Vietnam. He was born on September 26, 1989. He graduated from Chiba University in 2014. Currently, he is studying in the Department of Urban Environment Systems, Chiba University, Japan. 